\title{
Ortaokullarda Örgütsel Sinizmin Yordayıcısı Olarak Örgütsel Güven*
}

\section{Organizational Trust as a Predictor of Organizational Cynicism in Secondary Schools}

\author{
Burcu Uyar, ${ }^{a}$ Demet Zafer Güneş ${ }^{\mathrm{b} * *}$

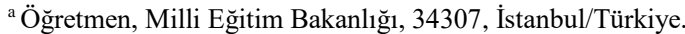 \\ ORCID: 0000-0003-4257-8583

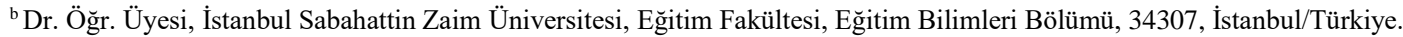 \\ ORCID: 0000-0002-1334-7199
}

\section{MAKALE BİLGİSI}

Makale Geçmişi:

Başvuru tarihi: 17 Ekim 2018

Düzeltme tarihi: 11 Kasım 2018

Kabul tarihi: 28 Kasım 2018

\section{Anahtar Kelimeler:}

Örgütsel Davranış

Örgütsel Güven

Örgütsel Sinizm

Öğretmen Görüşleri

\section{ARTICLE INFO}

\section{Article history:}

Received 17 October 2018

Received in revised form 11 November 2018

Accepted 28 November 2018

\section{Keywords:}

Organizational Behavior

Organizational Trust

Organizational Cynicism

Teacher Opinions

\section{ÖZ}

Bu çalışmanın temel amacı örgütsel sinizm ile örgütsel güven arasındaki ilişkiyi araştırmaktır. İlişkisel tarama modelindeki araştırmanın evrenini; İstanbul ili Küçükçekmece ilçesinde bulunan ortaokul öğretmenleri oluşturmakta olup, araştırmanın örneklemi ise n=390 (262 kadın; 128 erkek) ortaokul öğretmenidir. Çalışmada veri toplama aracı olarak kişisel bilgi formu, "Okullarda Örgütsel Güven Ölçeği" ve "Örgütsel Sinizm Ölçeği" kullanılmıştır. Sosyal bilimler için geliştirilen bir istatistik paket programı ile veriler analiz edilmiştir. Verilerin analizinde aritmetik ortalama, standart sapma, Pearson Korelasyon Testi ve doğrusal regresyon analizi kullanılmıştır. Araştırmada ortaokullarda görev yapan öğretmenlerde örgütsel güven ve örgütsel sinizm düzeyleri arasında istatistiksel açıdan negatif yönde, yüksek bir ilişki tespit edilmiştir. Ayrıca yapılan regresyon analizi sonucunda ortaokul öğretmenlerinin örgütsel güven düzeylerinin örgütsel sinizm düzeylerini yordama gücü $\% 52$ bulunmuştur.

\section{Giriş}

Diğer örgütlerdekine benzer biçimde eğitim örgütlerinde okul yöneticilerinin, öğretmenlerin ve diğer çalışanların karakterleri, inançları, hayat görüşleri, değer sistemleri, kültürleri, ilgi ve tutumları çeşitli faktörlerden etkilenmektedir (Kalağan ve Güzeller, 2010). Günümüzde hızla değişen ve farklılaşan çalışma dünyasında sadece

\begin{abstract}
verimlilik ve etkililiğin nasıl artırılacağı değil aynı zamanda çalışanlar için optimum çalışma ortamlarının nasıl olması gerektiği de tartışılmaya başlanmıştır. Ortamların çalışan davranışları ile ilişkili olduğu düşünüldüğünde; örgütsel güvenin sağlandığı ya da sağlanamadığı çalışma ortamının örgütsel sinizm ile ilişkisinin çalışan davranışını algılamada önemli olduğu düşünülmektedir.
\end{abstract}

\footnotetext{
*Bu çalışma, Marmara Üniversitesi ve İstanbul Sabahattin Zaim Üniversitesi Ortak Yüksek Lisans Programı kapsamında İstanbul Sabahattin Zaim Üniversitesi Sosyal Bilimler Enstitüsü’nde Dr. Öğretim Üyesi Demet ZAFER GÜNEŞ'in danışmanlı̆̆ında yürütülen "Öğretmenlerin örgütsel güven ve örgütsel sinizm düzeyleri arasındaki ilişki” başlıklı yüksek lisans tezinden üretilmiştir.

** Sorumlu yazar/Corresponding author e-posta: demet.gunes@izu.edu.tr
} 
Son yıllarda yapılan örgütsel davranış araştırmalarının ilgi alanına giren örgütsel sinizm, kişilerin örgütlerine karşı ortaya koydukları olumsuz tutumu ve inancı şeklinde tanımlanmaktadır (Özgener, Öğ̈̈t ve Kaplan, 2008; Dean, vd., 1998). Sinizm; hayal kırıklığı ve hüsran ile şekillenen, genel ve özel bir tavır olduğu gibi; bir kişiye, gruba, ideolojiye, sosyal sözleşmeye, kuruma veya yönetim şekline karşı güvensizlik ve negatif duygular-tavırlar biçiminde de ifade edilmektedir (Andersson ve Bateman, 1997; Wilkerson, 2002-Akt: Wilkerson vd., 2008).

Örgütsel sinizm örgütsel unsurlardan kaynaklanan, çevresel etkenlerle birlikte değişime açık, kişisel ve sosyal deneyimlerle bağlantılı bir kavramdır (Tokgöz ve Yılmaz, 2008; James, 2005). Örgütsel sinizmin üç alt boyutu (bilişsel, duyuşsal ve davranışsal) vardır. Sinizmin bilişsel boyutu bir işyerinde veya kurumda çalışanların bulundukları kurum ya da örgütün hakkaniyetli, adil ve dürüst olmaktan uzak olduğuna inanmalarıdır. Sinizm ile ilgili bilişsel boyut; direkt olarak bilinç yolu ile oluşturulurken duyuşsal boyut o kurum, örgüt ya da işyerine dair oluşturulan duygulardır (Dean vd., 1998). Bu sürecin sonucunda oluşan, örgüte yönelik fiili eylem ve eğilimler ise davranışsal boyut olarak ifade edilmektedir (Helvac1, 2010).

Sinizm özünde güven eksikliği olan bir kavramdır (Fieschi ve Heywood, 2004). Bu nedenle sinizmin örgütlere zarar verdiği ifade edilmektedir (Bibb ve Kourdi, 2004-Akt: Erbaşı ve Zaganjori, 2017). Bununla birlikte yapılan araştırmalarda sinizmin örgütsel vatandaşlık davranışını azalttığı (Mete ve Serin, 2015),çalışan bağlılığını düşürdüğü (Türköz, Polat ve Coşar, 2013), çalışanların yaşam doyumlarını azalttığı (Aslan ve Yılmaz, 2013) tespit edilmiştir. Alan yazında örgütsel sinizmin olumsuz bir örgütsel değişken olarak ele alındığı söylenebilir.

Kişilerin hayatının her evresinde gereksinim duyduğu güven olgusu bebeklikten itibaren ailede başlayarak, sosyal ilişkilerde, okulda, ekonomik ilişkilerde ve iş yaşamında yani insanın var olduğu her türlü ilişki ve ortamda istenilen bir olgudur (Erden, 2007). Kişiler arasında oluşan güven sadece hissedilerek anlaşılabilen, içgüdüsel olarak herkes tarafından anlaşılabilen bir kavramdır. Doğası gereği soyut bir nitelik taşımakta olup tanımlanması zor bir kavram olarak ifade edilmektedir (Hoy vd., 2002; Asunakutlu, 2002).

Bireyler arasındaki ilişkilerde güvenin önemi ne kadar fazla ise, kişinin örgüt ile ve örgütün birey ile olan ilişkilerinde de güven önemlidir. Güvenin örgütler için ilişkileri düzenleyen ve bir arada tutan bir bağ görevi yaptığı belirtilmektedir (Çokluk Bökeoğlu ve Yılmaz, 2008; Sağlam-Arı ve Tuncay, 2010). Çalışanların örgütün hedeflerini yerine getirme amaciyla motive eden ve örgütsel yaşamı kolaylaştıran güven; kişinin karşısındaki bireyin kararları, sözve davranışlarından emin olması ve bu yönde davranmasıdır (Sağlam-Arı ve Tuncay, 2010; Aslan ve Özata, 2009).

Örgütsel güvenin; yöneticiye güven, çalışanlara duyarlılık, yeniliğe açıklık ve iletişim ortamı olmak üzere dört alt boyutu vardır (Yılmaz, 2005). Çalışanların kararlarda söz sahibi olması çalışanlara duyarlılık alt boyutu ile ifade edilir. Yöneticiye güven; yöneticinin güvenilir ve dürüst olacağına dair inanç iken mesajların sağlıklı yürütülmesi iletișim ortamı alt boyutudur. Çalıșanların fikirlerine başvurulması ve bu fikirlerin yeri geldiğinde kullanılması ise yeniliğe açıklık boyutunda ifade edilir (Yılmaz, 2005; Yılmaz ve Sünbül, 2009).

Değişim sonucu ortaya çıkan belirsizliklerin hızlı bir şekilde arttığı günümüz dünyasında güven duygusunun eksikliği sürekli hissedilmektedir (Erdem, 2003). Bununla birlikte insan; güven duygusunu yaşantısının her aşamasında hissetmek ve görmek istemektedir (Yılmaz ve Sünbül, 2009). Okullarda da paydaşlar arasında güvene dayalı sosyal ilişkilerin olmasının okulun işleyişini olumlu yönde etkilediğini belirtilmektedir (Bryk ve Schneider, 2003).

Çalışanların birçok örgütsel ya da kişisel faktör sebebiyle sinik davranışları söz konusu olmakla birlikte güvenin bu faktörler arasında farklı bir öneme sahip olduğu söylenebilir. Bu kapsamda öğretmen davranışları ve okulun nasıl işlediğine dair yapılacak araştırmaların önemli olduğu düşünülmektedir. Okullarda, öğretmenlerin güvensiz bir ortamda görev yapmalarının birden çok soruna neden olabileceği (Taşdan ve Yalçın, 2010) ayrıca güvenin oluşmasında etkili olan öncüllerin sinizmin oluşmasında da etkili olduğu (Özler, Atalay ve Şahin, 2010) bilgisinden yola çıkarak araştırmada yanıt aranacak sorular şu şekilde planlanmıştır;

1. Araştırmaya katılan ortaokul öğretmenlerinin örgütsel güven ve örgütsel sinizm düzeyi nedir?

2. Ortaokullarda görev yapan öğretmenlerin örgütsel güven ve örgütsel sinizm düzeyleri ve alt boyutları arasında anlamlı bir ilişki var mıdır?

3. Ortaokullarda örgütsel güven, örgütsel sinizmin anlamlı bir yordayıcısı midır?

\section{Yöntem}

$\mathrm{Bu}$ bölümde araştırmanın modeli, evren ve örneklem sayıları, veri toplama araçları, verilerin toplanma süreci ve verilerin analizi kısımlarına dair bilgilere yer verilmiştir.

\subsection{Araştırmanın Modeli}

Öğretmenlerin örgütsel güven ve örgütsel sinizm düzeyleri arasındaki ilişkiyi belirlemeye yönelik yapılan bu çalışmada genel tarama modellerinden betimsel nitelikte ilişskisel tarama modeli kullanılmıştır. İlişkisel tarama modelleri, iki ya da daha fazla değişken arasında değişim olup olmadığını ve bu değişimin derecesini belirlemeyi amaçlayan araştırma modelleridir (Karasar, 2005).

\subsection{Evren ve Örneklem}

Araştırmanın evrenini 2016-2017 eğitim öğretim yılında İstanbul İli Küçükçekmece İlçesindeki ortaokullarda görev yapan $\mathrm{N}=1892$ öğretmen oluşturmaktadır. Bu çalışmada seçkisiz örnekleme yöntemlerinden basit seçkisiz örnekleme yöntemi kullanılmıştır. Örneklem belirlenirken Yazıcıoğlu ve Erdoğan (2004) tarafından hazırlanmış olan örneklem büyüklüğü hesaplama tablosundan yararlanılmıştır. Buna göre 0.05 örnekleme hatası $(\mathrm{p}=0.05$ ve $q=0.5$ ) ile en az $n=330$ öğretmenin katılımı örneklem için yeterli olarak değerlendirilmiştir. Bu nedenle ölçekler n=390 öğretmene uygulanmıştır. Araştırmaya katılan ortaokul öğretmenlerinin demografik özellikleri Tablo 1'de verilmiştir. 
Tablo 1. Araştırmaya Katılan Öğretmenlerin Demografik Özellikleri

\begin{tabular}{lccc}
\hline & \multicolumn{2}{c}{ Demografik özellikler Frekans } & $\begin{array}{r}\text { Yüzde } \\
(\boldsymbol{\%})\end{array}$ \\
\hline Cinsiyet & Kadın & 262 & 67.2 \\
Yaş & Erkek & 128 & 32.8 \\
& $20-25$ & 65 & 16.7 \\
& $26-30$ & 168 & 43.1 \\
& $31-35$ & 83 & 21.3 \\
Medeni Durum & $36-40$ & 44 & 11.3 \\
& 41 ue üzeri & 30 & 7.7 \\
Eğitim Düzeyi & Evli & 222 & 56.9 \\
& Bekâr & 168 & 43.1 \\
& Önlisans- & 344 & 88.2 \\
Toplam Hizmet Süresi & Lisans & 46 & 11.8 \\
& Lisansüstü & & \\
& $1-5$ yıl & 210 & 53.8 \\
& $6-10$ yil & 91 & 23.3 \\
& $11-15$ yll & 49 & 12.6 \\
& 16 y1l ve üzeri & 40 & 10.2 \\
\hline
\end{tabular}

Tablo 1 incelendiğinde, çalışmaya katılan 390 öğretmenden 262'si (\%67.2) kadın. 128'i (\%32.8) erkektir. Medeni durum açısından incelendiğinde, öğretmenlerin 168 'inin (\%43.1) bekâr. 222 'sinin (\%56.9) evlidir. Yaş değişkeni açısından. en yüksek oran 26-30 yaş $(\% 43.1)$ aralığındaki öğretmenlerdedir. Öğretmenlerin eğitim düzeyleri incelendiğinde, 344 kişi (\%88.2) önlisans-lisans.46 kişi (\%11.8) lisansüstü eğitim seviyesindedir. Toplam hizmet süresi değişkeni bakımından incelendiğinde $1-5$ yıl aralığında 210 öğretmen(\%53.8), 6-10 yıl aralığında 91 öğretmen(\%23.3), 11-15 y1l aralığında 49 öğretmen(\%12.6). 16yıl ve üzeri 40 öğretmen(\%10.2) araştırmaya katılmıştır.

\subsection{Veri Toplama Araçları}

Okullarda örgütsel güven ölçeği ve örgütsel sinizm ölçeği aracılığ1 ile veriler toplanmıştır. Öğretmenlerin örgütsel güven düzeyini ölçmek için Yılmaz (2005) tarafından okullara uyarlanan "Okullarda Örgütsel Güven Ölçeği”" kullanılmıştır. "Örgütsel Güven Ölçeği”, Daboval ve arkadaşları (1994) tarafından küçük işletmeler için geliştirilerek bir sempozyumda sunulmuş ve Türkçeye uyarlaması ise Kamer (2001) tarafından yapılmıştır. Yılmaz (2005) tarafından okullara uyarlaması yapılmıştır. Okullarda Örgütsel Güven Ölçeği; 40 maddelik ve dört alt boyuttan oluşan; "Tamamen katıliyorum" (6)' dan "Hiç katılmiyorum” (1)'a doğru puanlanan 6'lı Likert tipi bir ölçektir. Ölçeğin toplam güvenirlik katsayısı 0.97 bulunmuştur. $\mathrm{Bu}$ çalışmada ölçeğin toplam güvenirlik katsayısı $0.98^{\prime}$ dir. Ölçek geliştirme çalışmasında alt boyutların güvenirlik katsayıları "çalışanlara duyarlılık" 0.95; "yöneticiye güven" 0.95 ; "yeniliğe açıklık" 0.75 ve "iletişim ortamı" alt boyutu ise 0.92 bulunmuştur. Bu çalışmada ise ölçeğin alt boyutlarının güvenirlik katsayıları "çalışanlara duyarlılık" 0.93; "yöneticiye güven" 0.97; "yeniliğe açıklık" 0.85 ve "iletişim ortamı" alt boyutu ise 0.94 hesaplanmıştır.

Örgütsel Sinizm Ölçeği ise Brandes ve diğerleri (1999) tarafından geliştirilmiş ve Türkçeye Kalağan (2009) tarafindan uyarlanmıştır. "Örgütsel Sinizm Ölçeği” 13 maddelik ve 3 alt boyuttan oluşan; "Tamamen katılıyorum" (5). dan "Hiç katılmıyorum" (1)'a puanlanan 5'li Likert tipi bir ölçektir. Ölçeğin tüm maddeleri için Cronbach Alpha İç Tutarlılık Katsayısı 0.93 iken bu çalışmada 0.94 olarak bulunmuştur. Alt boyutları açısından bakıldığında "bilişsel" boyutta 0.91 . "duyuşsal" boyutta 0.95 ve "davranışsal" boyutta 0.87 olan güvenirlik katsayısı bu çalışmada ise "bilişsel" boyutta 0.89. "duyuşsal" boyutta 0.97 ve "davranışsal" boyutta da 0.85 olarak hesaplanmıştır.

\subsection{Verilerin Toplanmas 1}

Veriler araştırmacı tarafından 2016-2017 eğitim öğretim yılı mart ayında bizzat toplanmıştır. Veri toplama araçlarını dolduracak öğretmenler için yönerge sayfası hazırlanmıştır. Ayrıca sözlü açıklamalar da yapılarak öğretmenler araştırmanın amacı hakkında bilgilendirilmiştir. Ölçek formu toplam 450 ortaokul öğretmenine dağıtılmış, 420 tanesi geri dönmüştür. Bazı hatalı ve eksik doldurmalar nedeniyle 30 form analize dâhil edilmemiştir. Toplamda 390 ortaokul öğretmeninin görüşleri analize alınmıştır.

\subsection{Verilerin Analizi}

Verilerin analizinde sosyal bilimler için geliştirilen istatistik paket programı kullanılmıştır. Verilerin normal dağılımına ilişkin yapılan analiz sonucunda örgütsel güven için çarpıklık değeri 0.122 basıklık değeri -0.790; örgütsel sinizm için çarpıklık değeri 0.373 basıklık değeri -0.418 olarak hesaplanmıştır. Tabachnick ve Fidell'e göre (2013) çarpıklık ve basıklık değerlerinin \pm 1.5 . George ve Mallery'e (2010) göre ise \pm 2 aralığında yer alması normallik için kabul edilebilir bir durumdur. Buradan hareketle verilerin normal dağıldığı kabul edilmiştir. Ayrıca bağımlı ve bağımsız değişkenler arasında doğrusal bir ilişki olduğu saçılma diyagramı ile kontrol edilmiştir. Analizlerde örgütsel güven ve örgütsel sinizmin ile alt boyutlarının düzeyleri için ortalama ve standart sapma değerleri verilmiştir. Örgütsel güven ve örgütsel sinizm düzeyleri arasındaki ilişkiyi bulmak için korelasyon ve regresyon analizleri yapılmıştır.

\section{Bulgular ve Yorumlar}

Bu bölümde örgütsel güven ve örgütsel sinizm düzeyleri ile aralarındaki ilişkinin belirlenmesi amacıyla yapılan korelasyon ve regresyon analizlerinin sonuçlarına yer verilmiştir.

Tablo 2. Araştırmaya Katılan Öğretmenlerin Örgütsel Güven ve Örgütsel Sinizm Düzeyleri

\begin{tabular}{lccc}
\hline Alt Boyutlar & $\mathbf{n}$ & $\overline{\mathbf{X}}$ & SS \\
\hline Çalışanlara Duyarlılık & 390 & 3.39 & 1.04 \\
Yöneticiye Güven & 390 & 4.09 & 1.21 \\
İletişim Ortamı & 390 & 3.89 & 1.17 \\
Yeniliğe Açıkık & 390 & 3.71 & 1.21 \\
Örgütsel Güven & 390 & 3.76 & 1.06 \\
Bilişsel sinizm & 390 & 2.78 & .91 \\
Duyuşsal sinizm & 390 & 2.27 & 1.10 \\
Davranışsal sinizm & 390 & 2.92 & .96 \\
Örgütsel Sinizm & 390 & 2.66 & .86 \\
\hline
\end{tabular}

Tablo 2 incelendiğinde; ortaokul öğretmenlerinin algılarına göre, örgütsel güvenin çalışanlara duyarlılık alt boyutuna ilişkin puanlarının ortalaması $\overline{\mathbf{X}}=3.39$; yöneticiye güven alt boyutuna ilişkin puanlarının ortalaması $\overline{\mathbf{X}}_{=4.09}$; iletişim

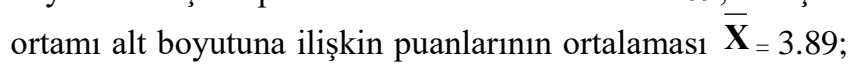


yeniliğe açıklık alt boyutuna ilişkin puanlarının ortalaması $\overline{\mathbf{X}}=3.71$ 'dir. Öğretmenlerin, örgütsel güven boyutunun puanlarının ortalaması $\overline{\mathbf{X}}_{=} 3.76$ olarak bulunmuştur. Araştırmaya katılan öğretmenlerin verdikleri yanıtların örgütsel güven ölçeğinde; yöneticiye güven alt boyutunda en yüksek olduğu söylenebilir. En düşük ortalama ise çalışanlara duyarlılık alt boyutundadır. Öğretmenlerin algılarına göre, örgütsel sinizmin alt boyutlarında en yüksek puan ortalaması davranışsal sinizim ( $\overline{\mathbf{X}}=2.92)$, daha sonra bilişsel sinizm ( $\left.\overline{\mathbf{X}}_{=} 2.78\right)$ en düşük iseduyuşsal sinizm $\left(\overline{\mathbf{X}}_{=}\right.$ 2.27) alt boyutuna ilişkin puanlarının ortalamasıdır. Öğretmenlerin, örgütsel sinizm boyutunun toplam puanlarının ortalaması $\overline{\mathbf{X}}=2.66$ olarak bulunmuştur.

Tablo 3. Örgütsel Güven Alt Boyutları ile Örgütsel Sinizm Alt Boyutları Arasındaki İlişkiye Ait Korelasyon Sonuçları

\begin{tabular}{|c|c|c|c|c|c|}
\hline & & Bilişsel & Duyuşsal & Davranışsal & $\begin{array}{c}\text { Örgütsel } \\
\text { Sinizm }\end{array}$ \\
\hline $\begin{array}{l}\text { Çalışanlara } \\
\text { Duyarlılık }\end{array}$ & $\mathrm{r}$ & $-.629 * *$ & $-.537 * *$ & $-.493 * *$ &.$-639 * *$ \\
\hline $\begin{array}{l}\text { Yöneticiye } \\
\text { Güven }\end{array}$ & $\mathrm{r}$ & $-.619 * *$ & $-.608 * *$ & $-.508 * *$ &.$-668 * *$ \\
\hline $\begin{array}{l}\text { İletişim } \\
\text { Ortamı }\end{array}$ & $\mathrm{r}$ & $-.675 * *$ & $-.640 * *$ & $-.567 * *$ &.$-724 * *$ \\
\hline $\begin{array}{l}\text { Yeniliğe } \\
\text { Açıklık }\end{array}$ & $\mathrm{r}$ & $-.590 * *$ & $-.563 * *$ & $-.527 * *$ &.$-645 * *$ \\
\hline $\begin{array}{l}\text { Örgütsel } \\
\text { Güven }\end{array}$ & $\mathrm{r}$ & $-.683 * *$ & $-.635^{* *}$ &.$-560 * *$ & $-.722 * *$ \\
\hline
\end{tabular}

$\mathrm{p}<.01$

Tablo 3'e göre örgütsel güvenin çalışanlara duyarlılık alt boyutu ile örgütsel sinizmin bilişsel sinizm alt boyutu $(r=-$ $.629 * *, \mathrm{p}<0.01)$, duyuşsal sinizmalt boyutu $(\mathrm{r}=-0.537 * *$, $\mathrm{p}<0.01)$ ve davranışsal sinizmalt boyutu $(\mathrm{r}=-0.493 * *$, $\mathrm{p}<0.01)$ arasında istatistiksel açıdan negatif yönde ve orta düzeyde anlamlı bir ilişki vardır. Örgütsel güvenin yöneticiye güven alt boyutu ile örgütsel sinizmin bilişsel sinizmalt boyutu $(\mathrm{r}=-0.619 * *, \mathrm{p}<0.01)$, duyuşsal sinizmalt boyutu $(\mathrm{r}=-0.608 * *, \mathrm{p}<0.01)$ ve davranışsal sinizmalt boyutu $\left(\mathrm{r}=-0.508^{* *}, \mathrm{p}<0.01\right)$ arasında istatistiksel açıdan negatif yönde ve orta düzeyde anlamlı bir ilişki vardır. Örgütsel güvenin iletişim ortamı alt boyutu ile örgütsel sinizmin bilişsel sinizmalt boyutu $\left(\mathrm{r}=-0.640^{* *}, \mathrm{p}<0.01\right)$, duyuşsal sinizmalt boyutu $(\mathrm{r}=-0.640 * *, \mathrm{p}<0.01)$ ve davranışsal sinizm alt boyutu $(\mathrm{r}=-0.567 * *, \mathrm{p}<0.01)$ arasında istatistiksel açıdan negatif yönde ve orta düzeyde anlamlı bir ilişki vardır. Örgütsel güvenin yeniliğe açıklık alt boyutu ile örgütsel sinizmin bilişsel sinizmalt boyutu ( $\mathrm{r}=$ $-0.590 * *, \mathrm{p}<0.01)$, duyuşsal sinizmalt boyutu( $\mathrm{r}=-0.563 * *$, $\mathrm{p}<0.01)$ ve davranışsal sinizmalt boyutu ( $\mathrm{r}=-0.527 * *$, $\mathrm{p}<0.01)$ arasında istatistiksel açıdan negatif yönde ve orta düzeyde anlamlı bir ilişki vardır. Sonuçlar incelendiğinde sinizmin tüm alt boyutlarında en yüksek korelasyon örgütsel güvenin iletişim ortamı alt boyutundadır.

Ortaokullarda görev yapan öğretmenlerin örgütsel güven ile örgütsel sinizm düzeyleri arasında istatistiksel açıdan negatif yönde, yüksek düzeyde ve anlamlı bir ilişki olduğu bulunmuştur $(\mathrm{r}=-0.722 * *, \mathrm{p}<0.01)$. Buna göre örgütsel güven puanı arttıkça örgütsel sinizm puanlarının azaldığı. örgütsel güven düzeyi yüksek olan öğretmenlerin örgütsel sinizm düzeylerinin düşük olduğu söylenebilir. Örgütsel sinizmin boyutları ile toplam örgütsel güven arasındaki ilişkiye bakıldığında her bir alt boyut ile arasında istatistiksel açıdan negatif yönde ve orta düzeyde anlamlı bir ilişki vardır. Toplam örgütsel güvenin en fazla bilişsel sinizm ile ilişkili olduğu söylenebilir $\left(\mathrm{r}=-.683^{* *}, \mathrm{p}<0.01\right)$.

Tablo 4. Örgütsel Güvenin Örgütsel Sinizme Etkisini Gösteren Regresyon Analizi Sonuçları

\begin{tabular}{lccccc}
\hline & $\mathbf{B}$ & Std. Hata & $\boldsymbol{\beta}$ & $\mathbf{t}$ & $\mathbf{p}$ \\
\hline Sabit & 4.878 & .111 & - & 43.755 & .000 \\
$\begin{array}{l}\text { Örgütsel } \\
\text { Güven }\end{array}$ & -.586 & .028 & -.722 & -20.577 & .000 \\
\hline
\end{tabular}

$\mathrm{R}=.72 . \mathrm{R}^{2}=.52$. Adj $\cdot \mathrm{R}^{2}=.52 . \mathrm{F}=$ 423.404. $\mathrm{p}<.01$

Örgütsel güven puanlarının örgütsel sinizm üzerine etkisini belirlemek amaciyla yapılan regresyon analizi sonucunda öğretmenlerin örgütsel güven düzeylerinin örgütsel sinizm düzeylerini yordama gücü \% 52 olduğu görülmektedir. Öğretmenlerin örgütsel güven düzeyleri, örgütsel sinizm düzeylerinin \% 52'sini açıklamaktadır $(\mathrm{p}<0.01)$.

Tablo 5. Örgütsel Güvenin Bilişsel Sinizm Boyutunda Örgütsel Sinizmi Yordamas1

\begin{tabular}{|c|c|c|c|c|c|}
\hline & B & $\begin{array}{l}\text { Std. } \\
\text { Hata }\end{array}$ & $\boldsymbol{\beta}$ & $\mathbf{t}$ & p \\
\hline Sabit & 5.00 & .124 & & 40.441 & .000 \\
\hline $\begin{array}{l}\text { Çalışanlara } \\
\text { Duyarlılık }\end{array}$ & -.242 & .054 & -.277 & -4.490 & .000 \\
\hline $\begin{array}{l}\text { Yöneticiye } \\
\text { Güven }\end{array}$ & -.036 & .066 & -.048 & -.544 & .587 \\
\hline $\begin{array}{l}\text { İletişim } \\
\text { Ortamı }\end{array}$ & -.359 & .067 & -.464 & -5.364 & .000 \\
\hline $\begin{array}{l}\text { Yeniliğe } \\
\text { Açıklık }\end{array}$ & -.040 & .059 & .053 & .676 & .499 \\
\hline
\end{tabular}

$\mathrm{R}=.70 . \mathrm{R}^{2}=49$. Adj. $\mathrm{R}^{2}=.48 . \mathrm{F}=90.973 . \mathrm{p}<.01$

Tablo 5'te örgütsel güvenin, bilişsel sinizm boyutunda örgütsel sinizmi yordama durumunu test eden modelin anlamlı olduğu görülmektedir $(\mathrm{F}=90.973, \mathrm{p}<.01)$. Güvenin alt boyutları bilişsel sinizm alt boyutunda sinizmin \%48'ini yordamaktadır $\left(\mathrm{R}^{2}=.48\right), \mathrm{T}$ değerleri incelendiğinde çalışanlara duyarlılık ve iletişim ortamı alt boyutlarının bilişsel sinizmin anlamlı yordayıcıları olduğu görülmektedir $(\mathrm{p}<.01) . \beta$ katsayılarına bakıldığında bilişsel sinizm alt boyutunda göreli en önemli yordayıcısının iletişim ortamı alt boyutunda yaşanan güven olduğu görülmektedir $(\beta=$ .464).

Tablo 6. Örgütsel Güvenin Duyuşsal Sinizm Boyutunda Örgütsel Sinizmi Yordaması

\begin{tabular}{lccccc}
\hline & B & $\begin{array}{c}\text { Std. } \\
\text { Hata }\end{array}$ & $\boldsymbol{\beta}$ & $\mathbf{t}$ & $\mathbf{p}$ \\
\hline Sabit & 4.765 & .159 & & 29.879 & .000 \\
$\begin{array}{l}\text { Çalışanlara } \\
\text { Duyarlılık }\end{array}$ & -.089 & .069 & -.084 & -1.286 & .192 \\
$\begin{array}{l}\text { Yöneticiye } \\
\text { Güven }\end{array}$ & -.159 & .085 & -.174 & -1.868 & .062 \\
$\begin{array}{l}\text { İletişim } \\
\text { Ortamı }\end{array}$ & -.402 & .086 & -.429 & -4.670 & .000 \\
$\begin{array}{l}\text { Yeniliğe } \\
\text { Açıklık }\end{array}$ & -.009 & .076 & -.010 & .120 & .499 \\
\hline
\end{tabular}

$\mathrm{R}=.65 \cdot \mathrm{R}^{2}=42$. Adj. $\mathrm{R}^{2}=.41 . \mathrm{F}=69.758 . \mathrm{p}<.01$ 
Tablo 6'da örgütsel güvenin. duyuşsal sinizm boyutunda örgütsel sinizmi yordamasını test eden modelin anlamlı olduğu görülmektedir $(\mathrm{F}=69.758, \mathrm{p}<.01)$. Güvenin alt boyutları duyuşsal sinizm alt boyutunda sinizmin \%42'sini yordamaktadır $\left(\mathrm{R}^{2}=.42\right), \mathrm{T}$ değerleri incelendiğinde yalnızca iletişim ortamı alt boyutunun duyuşsal sinizmin anlamlı yordayıcısı olduğu görülmektedir $(\mathrm{p}<.01)$.

Tablo 7. Örgütsel Güvenin Davranıșsal Sinizm Boyutunda Örgütsel Sinizmi Yordaması

\begin{tabular}{lccccc}
\hline & $\mathbf{B}$ & $\begin{array}{c}\text { Std. } \\
\text { Hata }\end{array}$ & $\boldsymbol{\beta}$ & $\mathbf{t}$ & $\mathbf{p}$ \\
\hline Sabit & 4.800 & .149 & & 32.271 & .000 \\
$\begin{array}{l}\text { Çalışanlara } \\
\text { Duyarlılık }\end{array}$ & -.090 & .065 & -0.97 & -1.388 & .166 \\
$\begin{array}{l}\text { Yöneticiye } \\
\text { Güven }\end{array}$ & .069 & .079 & .087 & .873 & .383 \\
$\begin{array}{l}\text { İletişim } \\
\text { Ortamı }\end{array}$ & -.349 & .080 & -.427 & -4.338 & .000 \\
$\begin{array}{l}\text { Yeniliğe } \\
\text { Açıklık }\end{array}$ & -.134 & .071 & -.170 & -1.902 & .058 \\
\hline
\end{tabular}

$\mathrm{R}=.58 \cdot \mathrm{R}^{2}=33$. Adj $\cdot \mathrm{R}^{2}=.32 . \mathrm{F}=48.503 . \mathrm{p}<.01$

Tablo 7'de örgütsel güvenin, davranışsal sinizm alt boyutunda örgütsel sinizmi yordamasını test eden modelin anlamlı olduğu görülmektedir $(\mathrm{F}=48.503, \quad \mathrm{p}<.01)$. Güvenin alt boyutları davranışsal sinizm alt boyutunda sinizmin \%32'sini yordamaktadır $\left(\mathrm{R}^{2}=.32\right)$. Davranışsal sinizmin anlamlı yordayıcısının yalnızca iletişim ortamı alt boyutu olduğu görülmektedir $(\mathrm{p}<.01)$.

\section{Sonuç ve Öneriler}

Araştırma sonucunda ortaokul öğretmenlerinin verdikleri yanıtların örgütsel güven ölçeğinde; en yüksek yöneticiye güven alt boyutunda en düşük ise çalışanlara duyarlılık alt boyutunda olduğu bulunmuştur. Örgütsel güven ölçeğindeki puan ortalamaları önceki araştırma sonuçları ile örtüşmektedir (Demirdağ, 2017; Ayduğ ve Ağaoğlu, 2017; Altunay, 2017;Sağlam, 2016; Cemaloğlu ve Kılınç, 2012; Çağlar, 2011; Polat, 2010).Ortaokul öğretmenlerin algılarına göre, örgütsel sinizmin alt boyutlarında en yüksek puan ortalaması davranışsal sinizm, daha sonra bilişsel sinizm, en düşük ise duyuşsal sinizm alt boyutuna ilişkin puanlarının ortalamasıdır. Örgütsel sinizm puan ortalaması diğer araştırma sonuçları ile benzerlik göstermektedir (Güçlü, Kalkan ve Dağl1, 2017; Mete ve Serin, 2015; Sezgin-Nartgün ve Kartal, 2013; Kalağan ve Güzeller, 2010).

Araştırmaya katılan ortaokullarda görev yapan öğretmenlerin örgütsel güven ile örgütsel sinizm düzeyleri arasında istatistiksel açıdan negatif yönde, yüksek ve anlamlı bir ilişki bulunmuştur. Örgütsel güven düzeyi yüksek olan öğretmenlerin örgütsel sinizm düzeylerinin düşük olduğu söylenebilir. Farklı örgütlerde yapılan araştırmalarda örgütsel güven ve örgütsel sinizm arasında negatif yönde ve anlamlı ilişki bulunmuştur (Mino, 2002; Karcıoğlu, 2013; Türköz, Polat ve Coşar, 2013; Yıldırım, 2014; Karcioğlu ve Naktiyok, 2015; Cesur-Yeşilçimen, 2015; Reyhanoğlu ve Yılmaz, 2017). Bununla birlikte eğitim örgütlerinde yapılan araştırmalarda da öğretmenlerin örgütsel güven ve örgütsel sinizm düzeyleri arasında negatif yönde bir ilişki olduğu yani örgüte duyulan güven arttıkça sinizmin azaldığı sonucuna ulaşılmıştır (Polat, 2013; Güler, 2014; Akın, 2015; Yakın, 2017; Dağyar ve Kasalak, 2018). Araştırma sonucu literatürdeki araştırma sonuçları ile örtüşmekle birlikte literatürdeki "güvenin yüksek olduğu kurumlarda sinik davranışlar daha az görülmektedir ya da "güvensiz ortam sinik davranışların sebeplerindendir" (Kalağan, 2009; Özler vd. 2010; Türköz vd., 2013) bilgisi ile de paraleldir. Bu bulgu öğretmenlerde görülecek sinizme dair davranışlarda okul ortamında oluşturulan güvenin önemine dair eğitim yöneticilerine yol gösterebilir.

Toplam örgütsel güvenin görece en fazla bilişsel sinizm ile ilişkili olduğu sonucuna ulaşılmıştır.Araştırmanın bu bulgusunun olası nedeninin; örgütsel sinizmin inanç ile başladığı (Özgener vd., 2008) bilgisine dayanabileceği söylenebilir.Örgütsel güvenin alt boyutlarının her biri ile örgütsel sinizmin alt boyutları arasında da istatistiksel açıdan negatif yönde,orta düzeyde ve anlamlı bir ilişki bulunmuştur. Sonuçlar incelendiğinde sinizmin tüm alt boyutlarında en yüksek korelasyon örgütsel güvenin iletişim ortamı alt boyutundadır. Ayık (2015) araştırmasında örgütsel iletişim ile örgütsel sinizmin duyuşsal, bilişsel ve davranışsal sinizm alt boyutları arasında negatif yönlü ve anlamlı bir ilişki bulmuştur. Benzer biçimde Polat (2014) da okullarda kurum içi etkin iletişim ortamı ile örgütsel sinizm arasında negatif yönlü ve anlamlı bir ilişki bulmuştur. Farklı araştırmalarda da etkili iletişimin; örgütteki çalışanları güdülediği (Yılmaz, 2005), çalışanların sinizm algılarını düşürdüğü (Kanbur ve Kanbur, 2015; Tinaztepe, 2012) bulunmuştur. Ayrıca Ayık ve Uzun (2016) ile Quian ve Daniels (2008) araştırmalarında iletişimin örgütsel sinizmi yordadığını rapor etmişlerdir. İletişim ortamı alt boyutunun örgütsel sinizm ile diğer alt boyutlara göre görece yüksek korelasyonu, alan yazındaki araştırma sonuçları ile örtüşmektedir. $\mathrm{Bu}$ bulgu ortaokullarda görülecek örgütsel sinizmin azaltılmasında, okulda oluşturulacak iletişim ortamının görece önemini ortaya koymaktadır. Olumlu iletişim ortamında öğretmenlerin motivasyon ve performans düşüklüklerinin azalacağı söylenebilir.

Ortaokul öğretmenlerin örgütsel güven düzeylerinin örgütsel sinizm düzeylerini yordama gücü \% 52 olarak bulunmuştur. $\mathrm{Bu}$ bulgu önceki araştırma sonuçları ile benzerdir (Polat, 2013; Türköz vd., 2013;Biswas ve Kapil, 2017). Örgütsel sinizm ile ilgili yapılan çalışmalarda, örgütsel güvenin örgütsel sinizmin öncülleri arasında yer aldığ1 görülmektedir (Dağyar ve Kasalak, 2018). Örgütsel güvenin her bir alt boyutunun örgütsel sinizmin alt boyutlarını yordamasını test eden modelde; güvenin alt boyutları davranışsal sinizm alt boyutunda sinizmin \%32'sini, duyuşsal sinizm alt boyutunda sinizmin \%42'sini, bilişsel sinizm alt boyutunda sinizmin \%48'ini yordadığı bulunmuştur. Sonuçlar ayrıntılı incelendiğinde örgütsel güvenin; çalışanlara duyarlılık ve iletişim ortamı alt boyutlarının bilişsel sinizmin anlamlı yordayıcıları olduğu görülmektedir. Davranışsal ve duyuşsal sinizmin anlamlı yordayıcısı ise örgütsel güvenin iletişim ortamı alt boyutudur. İletişim ortamı alt boyutunun örgütsel sinizmin tüm alt boyutlarının anlamlı yordayıcısı olduğu bulunmuştur. Hoy vd. (2003)' e göre okulun örgütsel güven düzeyi, okuldaki ilişkilerin bir ürünüdür. İletişim ortamı alt boyutunun örgütsel sinizmin tüm alt boyutlarının anlamlı 
yordayıcısı olması önemli görülmektedir. Okullarda oluşturulacak güven ortamının öğretmenlerin okula karşı olumlu tutumlarını artırabileceği söylenebilir. Örgütsel sinizmin ortaya çıkma nedenleri arasında örgütsel güvenin olduğu bulunmuştur.

Araştırma İstanbul ili Küçükçekmece ilçesinde görev yapan ortaokul öğretmenlerinin görüşleri ile sınırlıdır. Farklı illerde ve farklı eğitim kademelerinde çalışan öğretmenler ile araştırma tekrarlanabilir. Örgütsel sinizmin, örgütsel güven ile ilişkisi ayrıntılı olarak araştırılmıştır. Örgütsel sinizm ile ilişkili olabilecek farklı konular ve farklı metodolojilerle araştırmalar yapılabilir. Örgütsel güvenin yüksek olduğu okullarda örgütsel sinizmin azaldığı göz önüne alındığında okul müdürlerinin okullardaki uygulamalarda örgütsel güvenin artmasına dikkat etmeleri önerilebilir. Bununla birlikte okullardaki iletişim ortamının iyileştirilmesi için okul müdürleri, tüm iletişim kanallarını açık tutarak okulda çift yönlü bir iletişim sağlanmasına özen gösterebilirler. Yönetsel iletişim ile ilgili hizmet içi eğitim ve seminerler düzenlenebilir.

\section{Kaynakça}

Akın, U. (2015). Okullarda örgütsel sinizm ve güven ilişkisinin incelenmesi: öğretmenler üzerinde bir araştırma. Eğitim ve Bilim, 40(181), 175-189.

Andersson, L. M. \& Bateman, T. S. (1997). Cynicism in the workplace: some causes and effects. Journal of Organizational Behavior, 18,449-469.

Altunay, E. (2017). İlköğretim okulu öğretmenlerininörgütsel güven ve adanmışlık düzeyleriarasındaki ilişkinin incelenmesi, Milli Ĕgitim Dergisi, 213, 37-66.

Aslan, H. \& Y1lmaz, E. (2013). The study of teachers' general cynicism inclinations in terms of lifesatisfaction and other variables. Creative Education, 4(9), 588-591.

Aslan, Ş. \& Özata, M. (2009). Lider-üye etkileşiminin (LMX) yöneticiye duyulan güven düzeyine etkisi. Selçuk Üniversitesi İktisadi ve İdari Bilimler Fakültesi Dergisi,11(9), 95-116.

Asunakutlu, T. (2002). Örgütsel güvenin oluşturulmasına ilişkin unsurlar ve bir değerlendirme. Muğla Üniversitesi Sosyal Bilimler Enstitüsü Dergisi,9, 1- 13.

Ayduğ, D. \& Ağaoğlu, E. (2017). İlkokullarda örgüt sağlığ1 ile öğretmenlerin örgütsel güven düzeyleri arasındaki ilişki. Anadolu Üniversitesi Eğitim Fakültesi Dergisi,1 (1), 1-17.

Ayık, A. (2015). An analysis of the relationship between organizational communication and organizational cynicism according to teachers' perceptions in Turkey. Educational Research and Review, 10(5), 547-555.

Ayık, A. \& Uzun, T. (2016). Okul Müdürlerinin iletişim becerileri ile öğretmenlerin genel ve örgütsel sinizm tutumları arasındaki ilişsilerin incelenmesi. Mersin Üniversitesi Eğitim Fakültesi Dergisi, 12(2), 672-688.

Biswas, S. \& Kapil, K. (2017). Linking perceived organizational support and organizational justice to employees' in-role performance and organizational cynicism through organizational trust. Journal of Management Development, 36(5), 696-711.

Bryk, A. S. \& Schneider, B. (2003). Trust in schools: a core resource for school reform. Educational Leadership, 60(6), 40-45.

Cemaloğlu, N. \& Kılınç, A.Ç. (2012). İlköğretim okulu yöneticilerinin etik liderlik davranışları ile öğretmenlerin algıladıkları örgütsel güven ve yıldırma arasındaki ilişki. Eğitim ve Bilim, 37(165), 137-151.

Cesur Yeşilçimen, K. (2016). Hemşirelikte örgütsel sinizm ve örgütsel güven ilişkisi. Yayınlanmamış Yüksek Lisans Tezi. İstanbul:İstanbul Üniversitesi.

Çağlar, Ç. (2011). Okullardaki örgütsel güven düzeyi ile öğretmenlerinmesleki tükenmişlik düzeyinin bazı değişkenleraçısından incelenmesi, Kuram ve Uygulamada Eğitim Bilimleri, 11(4), 1827-1847.

Çokluk-Bökeoğlu, Ö. \& Yılmaz, K. (2008). İlköğretim okullarında örgütsel güven hakkında öğretmen görüşleri. Kuram ve Uygulamada Eğitim Yönetimi.54,211-233.

Dağyar, M. \& Kasalak, G. (2018). Eğitim örgütlerinde yaşanan örgütsel sinizmin öncülleri ve sonuçları üzerine bir meta-analiz çalışması. Hacettepe Üniversitesi Ĕ̆itim Fakültesi Dergisi,1-20. doi: 10.16986/HUJE.2018037797.

Dean, J. W., Brandes, P. \& Dharwadkar, R. (1998). Organizational cynicism. Academy of Management Review, 23(2), 341-352.

Demirdağ, S. (2017). Ücretli öğretmen algılarına göre ilkokul yöneticilerinin örgütsel adalet,örgütsel güven ve yıldırma davranışları arasındaki ilişki. Abant İzzet Baysal Üniversitesi Eğitim Fakültesi Dergisi, 17(1), 132-153.

Erbaşı, A. \& Zaganjori, O. (2017). Sosyal izolasyonun örgütsel sinizm üzerindeki etkisi. Yönetim ve Ekonomi,24(1), 39-52.

Erden, A. (2007). Ankara ve Lefkoşa okul yöneticilerinin ve öğretmenlerinin örgütsel güvene ilişkin görüşleri. Yayınlanmamış Doktora Tezi. Ankara:Ankara Üniversitesi.

Erdem, F. (2003). Örgütsel yaşamda güven. Ferda Erdem (Der). Sosyal Bilimlerde Güven.(ss.153-183). Ankara: Vadi Yayınları.

Fieschi, C. \& Heywood, P. (2004). Trust. cynicism and populist anti-politics. Journal of Political Ideologies.9(3), 1-27.

George. D. \& Mallery, M. (2010). SPSS for windows step by step: A simple guide and reference. (10. Bask1.) Boston: Pearson.

Güçlü, N.; Kalkan, F. \& Dağlı, F. (2017). Mesleki ve teknik ortaöğretim okulu öğretmenlerinalgılarına göre okul müdürlerinin liderlik stilleriile örgütsel sinizm arasındaki ilişki. Gazi Üniversitesi Gazi Ĕ̆itim Fakültesi Dergisi, 37(1): 177-192. 
Güler, S. (2014). Örgütlerde güven algılamasının örgütsel sinizm üzerine etkisi ve bir araştırma. Yayınlanmamış Yüksek Lisans Tezi. Denizli: Pamukkale Üniversitesi.

Helvac1, M. A. (2010). Örgütsel sinizm. H. Basri Memduhoğlu ve. K. Yılmaz (Ed.). Yönetimde yeni yaklaşımlar içinde (ss.383-397). Ankara: Pegem A Yayınc1lık.

Hoy, W. K.. Smith. P. A. \& Sweetland. S. R. (2002). The Development Of The Organizational Climate İndex For High Schools: Its Measure And Relationship To Faculty Trust. The High School Journal, 86(2), 38-49.

Hoy, W. K. \& M.,Tschannen-Moran. (2003). The conceptualization andMeasurement of Faculty Trust In Schools: The Omnibus T-Scale. In W. K.Hoy \& C. G. Miskel (Eds.), Studies in Leading and Organizing Schools (ss. 181-208). Greenwich: CT.: Information Age Publishing.

James, M. S. L. (2005). Antecedents ve consequences of cynicism inorganizations: an examination of thepotential positive and negative effects on school system. Yayınlanmamış Doktora Tezi. Florida: The Florida State University.

Kalağan, G. (2009). Araştırma görevlilerinin örgütsel destek alglları ile örgütsel sinizm tutumları arasındaki ilişki. Yayınlanmamış Yüksek Lisans Tezi. Antalya: Akdeniz Üniversitesi.

Kalağan, G. \& Güzeller, C. O. (2010). Öğretmenlerin örgütsel sinizm düzeylerinin incelenmesi. Pamukkale Üniversitesi Ĕ̌itim Fakültesi Dergisi,27, 83-97.

Kanbur, A. \& Kanbur. E. (2015). Lider-üye etkileşiminin örgütsel sinizme etkisi: algılanan içsellik statüsünün arac1lık rolü. Zeitschrift für die Welt der Türken/Journal of World of Turks, 7(2). 193-216.

Karasar, N. (2005). Bilimsel araştırma yöntemi. Ankara: Nobel Yayın Dağıtım.

Karcioğlu, M. S. (2013). Örgütsel ortamda algllanan güven düzeyinin sinizm üzerindeki rolü: Atatürk Üniversitesi idari personeli üzerinde bir araştırma. Yayınlanmamış Yüksek Lisans Tezi. Erzurum: Atatürk Üniversitesi.

Karcioğlu, M.S. \& Naktiyok, A. (2015). Örgütsel ortamda algılanan güven düzeyinin sinizm üzerindeki rolü: Atatürk üniversitesi idari personeli üzerinde bir araştırma. $A K \ddot{U}$ IIIBF Dergisi, 17(1), 19-34.

Mete, Y. M.\& Serin, H. (2015). Okul yöneticilerinin babacan liderlik davranışı ile öğretmenlerin örgütsel vatandaşl1k ve örgütsel sinizm davranışları arasındaki ilişki. Hasan Ali Yücel Eğitim Fakültesi Dergisi, 122(24), 147-159.

Mino, C.E. (2002). Organizational trust, organizational cynicism and organizational commitment during a change initiative. Yayımlanmamış Doktora Tezi. California: Alliant International University.

Özler, D. E., Atalay, C. G. \& Şahin, M. D. (2010). Örgütlerde sinizm güvensizlikle mi bulaşır?. Organizasyon ve Yönetim Bilimleri Dergisi,2(2), 47-57.
Özgener, Ş., Öğüt, A. \& Kaplan, M. (2008). İş görenişveren ilişkilerinde yeni bir paradigma: örgütsel sinizm. M. Özdevecioğlu ve H. Karadal (Ed.). Örgütsel davranışta seçme konular: organizasyonların karanlık yönleri ve verimlilik azaltıcı davranışlar içinde (ss.5372). Ankara:İlke Yayınevi.

Polat, S. (2010). The effect of organizational support; Perception of teachers on organizational trust perception of their schools. African Journal of Business Management, 4(14), 3134-3138.

Polat, S. (2013). The impact of teachers' organizational trust perceptions on organizational cynicism perception. Educational Research and Reviews, 8(16), 1483-1488.

Polat, E. (2014). Kurum içi etkin iletişim ortamı ile örgütsel sinizm arasındaki ilişki: ögrretmenlerin görüşleri açısından incelenmesi. Yayınlanmamış Yüksek Lisans Tezi. Kayseri:Erciyes Üniversitesi.

Qian, Y. A. \& Daniels, T. D. (2008). A communication model of employee cynicism toward organizational change. Corporate Communication: An International Journal, 13(3), 319-332.

Reyhanoğlu, M. \& Y1lmaz, H. (2017). Örgütsel güvenin sağlamasında sinizmin etkisi: havalimanı güvenlik memurları örneği. Trakya Üniversitesi Sosyal Bilimler Dergisi, 19(2),297-317.

Sağlam-Arı, G. \& Tuncay, A. (2010). Yöneticiye duyulan güven ve tükenmişlik arasındaki ilişkiler: Ankara'daki devlet hastanelerinde çalışan idari personel üzerinde bir araştırma. Atatürk Üniversitesi İktisadi ve İdari Bilimler Dergisi, 24(4),113-135.

Sağlam, A.Ç. (2016). The effects of vocational high school teachers' perceived trust onorganizational silence. Journal of Education and Training Studies, 4(5), 225232.

Sezgin-Nartgün, S.Ş. \& Kartal,V. (2013). Öğretmenlerin örgütsel sinizm ve örgütsel sessizlik hakkındaki görüşleri. Bartın Üniversitesi Eğitim Fakültesi Dergisi, 2(2), 47-67.

Tabachnick, B.G. \& Fidell, L.S. (2013). Using multivariate statistics (6. Bask1) Boston: Pearson.

Taşdan, M. \& Yalçın, T. (2010). İlköğretim Okulu öğretmenlerinin algıladıkları sosyal destek ile örgütsel güven düzeyleri arasındaki ilişki Düzeyi. Kuram ve Uygulamada Ĕ̈itim Bilimleri, 10(4), 2569-2620.

Tınaztepe, C. (2012). Örgüt içi etkin iletişimin örgütsel sinizme etkisi. Organizasyon ve Yönetim Bilimleri Dergisi, 4(1), 53-63.

Tokgöz, N.\& Yılmaz, H. (2008). Örgütsel sinizm: Eskişehir ve Alanya'daki otel işletmelerinde bir uygulama. Anadolu Üniversitesi Sosyal Bilimler Dergisi, 8(2), 283-305.

Türköz, T., Polat, M. \& Coşar, S. (2013). Çalışanların örgütsel güven ve sinizm algılarının örgütsel bağlılıkları üzerindeki rolü. Yönetim ve Ekonomi,20(2), 285-302. doi: 10.18657/yecbu.55607 
Wilkerson, J. M., Evans, W. R. \& Davis, W. D. (2008). A test of coworkers' influence on organizational cynicism. badmouthing. and organizational citizenship behavior. J. Appl. Soc. Psychol,38, 2273-2292.

Yakın, B. (2017). Örgütsel güven. örgütsel özdeşleşme ve örgütsel sinizm ilişkisi. Yayınlanmamış Yüksek Lisans Tezi. Ankara:Gazi Üniversitesi.

Yazıcıŏlu, Y. \& Erdoğan, S. (2004). Spss uygulamal bilimsel araştırma yöntemleri. Ankara: Detay Yayıncilik.
Yıldırım, M. (2014). Psikolojik sözleşme ihlallerinin örgütsel güven ve örgütsel sinizm ile ilişkisi: Otel işletmeleri üzerine bir araştırma. Yayınlanmamış Doktora Tezi. Ankara: Gazi Üniversitesi.

Yılmaz, E. (2005). Okullarda örgütsel güven ölçeğinin geçerlik ve güvenirlik çalışması. Selçuk Üniversitesi Sosyal Bilimler Dergisi,14, 567-580.

Yılmaz, E. \& Sünbül. A. M. (2009). Öğretmenlerin yaşam doyumları ve okullardaki örgütsel güven düzeyi. Journal of Qafqaz University, 26(1),172-179. 